https://doi.org/10.37208/tgn27218

\section{A shark louse from a porbeagle shark stranded near Arbroath, Scotland}

\author{
M. O’Reilly ${ }^{1}$ \& G. Hantke ${ }^{2}$ \\ ${ }^{1}$ Scottish Environment Protection Agency, Angus Smith \\ Building, 6 Parklands Avenue, Eurocentral, Holytown, \\ North Lanarkshire ML1 4WQ \\ ${ }^{2}$ National Museums Scotland, Chambers Street, \\ Edinburgh EH1 1JF \\ E-mail: myles.oreilly@sepa.org.uk
}

The Scottish Marine Animal Stranding Scheme (SMASS) is responsible for examining stranded whales, dolphins, seals, marine turtles and basking sharks on Scotland's shores (SMASS, 2016). Post mortem investigations are carried out on a number of the stranded animals to establish a cause of death and to monitor and report on the species in Scottish waters.

On 4th August 2019 a porbeagle shark (Lamna nasus) was found washed ashore near Arbroath, Angus, Scotland (NO6390840173) (Fig. 1). The specimen, a $214 \mathrm{~cm}$ male weighing $70 \mathrm{~kg}$, was reported to SMASS. This species is currently not part of SMASS's remit, and instead the stranding was attended by curators of the National Museum of Scotland. During the examination a single shark louse (a parasitic copepod) found attached to the shark was removed for deposition in the museum (Reg. NMSZ 2019.70). Necropsy samples were also taken and the carcass was returned to the museum and frozen for further study.

Parasitic copepods are well known as external parasites on fishes in British seas with nearly 130 species known from British waters (Kabata, 1979, 1992). Perhaps the most widely known species are the sea louse (Caligus elongatus) and salmon louse (Lepeophtheirus salmonis), both serious pests of farmed salmon (Salmo spp.), and the gill maggot (Lernaeocera branchialis), which attaches to the gills of over a dozen fish species. Different copepod species have different host affinities but some utilise a wide variety of hosts. The common sea louse (C. elongatus) has been found on over 100 fish species and has also been found on whales (O’Reilly, 1998; Ólafsdóttir \& Shinn, 2013). However, there is a problem with many $C$. elongatus host records since molecular data suggest it comprises two cryptic species (Øines \& Heuch, 2005).

Six different parasitic copepod species are recorded from porbeagles in British waters. Two of these Nemesis robusta and Phyllothyreus cornutus - attach



Fig. 1. Stranded porbeagle shark (Lamna nasus), $214 \mathrm{~cm}$ in length, on the shore near Arbroath, Angus, Scotland. (Photo: G. Hantke)

only to the gill filaments. One - Anthosoma crassum lives half embedded in the skin of its host with only the posterior protruding. Another species - Ommatokoita elongata - always attaches to the eye of its host, which is usually the Greenland shark (Somniosus microcephalus), and has only very rarely been found on porbeagles. The remaining two species - Dinemoura producta and Echthrogaleus coleoptratus - attach to the body or fins of their host, particularly to the trailing edge of the fins. They are both in the family Pandaridae with the adult females in the size range $10-18 \mathrm{~mm}$. D. producta is up to $18 \mathrm{~mm}$ in length with an elongate two-segmented abdomen; E. coleoptratus is up to $14 \mathrm{~mm}$ in length with a shorter one-segmented abdomen.

The copepod collected from the porbeagle shark was 18 $\mathrm{mm}$ long (Fig. 2) and was found attached laterally, about $40 \mathrm{~cm}$ anterior to the tail fluke. It has a rounded shield-like cephalothorax with a pair of medial eyes and an elongated posterior trunk. Although slightly damaged, its trunk structure indicated it to be an adult female $D$. producta.

Scott \& Scott (1913) describe D. producta as a common finding from porbeagles with Scottish records from Shetland, Moray Firth, Aberdeen (fish market), south to Berwick-upon-Tweed Bay off the Scottish Borders, and an English record from Cornwall. They also cite a record from a thresher shark (Alopias 


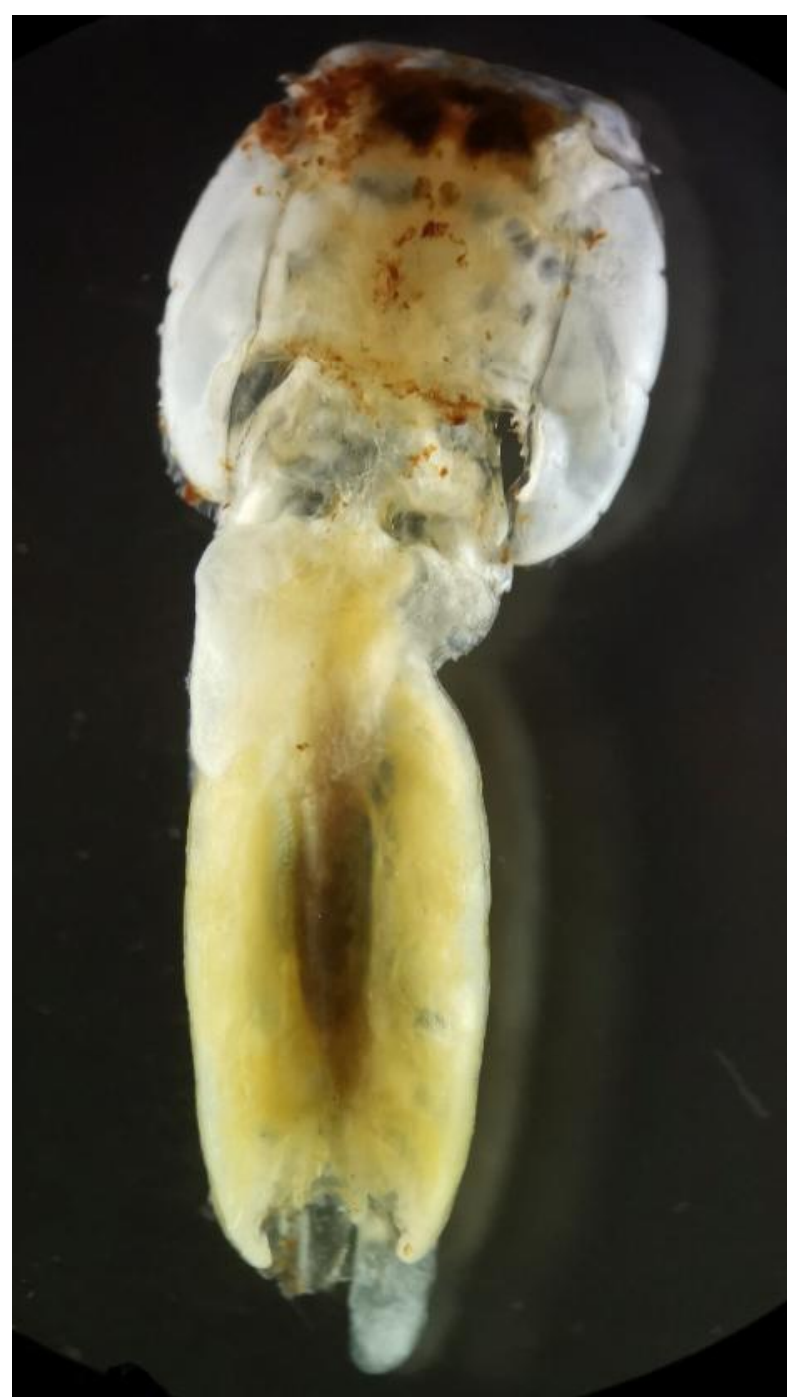

Fig. 2. Dorsal view of female shark louse (Dinemoura producta), $18 \mathrm{~mm}$ in length, from the stranded porbeagle shark (Lamna nasus). (Photo: R. Eustace)

vulpinus) in the Firth of Tay. The Plymouth Marine Fauna cites its occurrence on basking sharks (Cetorhinus maximus) (Marine Biological Association, 1957). Kabata (1992) refers to it as common in all sea areas of Britain, indicating its hosts in British waters include the spurdog (Squalus acanthias) and also the thresher, blue (Prionace glauca), porbeagle, shortfin mako (Isurus oxyrinchus), and basking sharks. D. producta is well known to occur on basking sharks off the coast of Scotland (Matthews \& Parker, 1951) and Ireland (Scott, 1963). Adult female copepods carry a pair of egg sacs which are usually white when laid but become darker as they near hatching. Ovigerous female D. producta, bearing white eggs strings several centimetres long, may be quite conspicuous on basking sharks in U.K. waters and can sometimes be seen on video clips of slow swimming basking sharks on television documentaries or posted on the internet. An encounter with a basking shark off the Isle of Man, filmed with a pole-mounted camera by a kayaker (Rathore, 2018), shows numerous ovigerous copepods attached to the trailing edge of the large dorsal fin and the pelvic fins and also on the upper body between the dorsal fin and the tail fluke.

Stranded sharks are relatively unusual, although even an occasional basking shark has been found on beaches (BBC, 2016). The accurate identification of ectoparasites on British sharks requires careful examination. Given that observations are relatively scarce and hosts are difficult to sample, sourcing specimens for study relies on the sampling of sharks stranded on the shore or accidentally by-caught in fisheries.

The authors wish to thank Mariel ten Doeschate (SMASS) for informing us about the stranding and for helpful comments on this note, Fiona Ware (National Museums Scotland) for making the shark louse available for examination, and Ryan Eustace (SEPA) for provision of the copepod photo.

\section{REFERENCES}

BBC (2016). Dead 15ft basking shark washes up in Scotland. BBC News website 19th February 2016. https://www.bbc.co.uk/news/uk-scotland-glasgowwest-35613371

Kabata, Z. (1979). Parasitic Copepoda of British Fishes. The Ray Society, London.

Kabata, Z. (1992). Copepods Parasitic on Fishes. Synopses of the British Fauna (New Series) No.47. Universal Book Services/Dr. W. Backhuys.

Marine Biological Association (1957). Plymouth Marine Fauna. Compiled from the Records of the Laboratory of the Marine Biological Association of the United Kingdom. (3rd Edition). Marine Biological Association, Plymouth.

Matthews, L.H. \& Parker, H.W. (1951). Notes on the anatomy and biology of the Basking Shark (Cetorhinus maximus (Gunner)). Proceedings of the Zoological Society of London 120, 535-576. https://doi.org/10.1111/j.10963642.1950.tb00663.x

Øines, O. \& Heuch, P.A. (2005). Identification of sea louse species of the genus Caligus using mtDNA. Journal of the Marine Biological Association of the United Kingdom 85, 73-79. https://doi.org/10.1017/S0025315405010854h

Ólafsdóttir, D., \& Shinn, A.P. (2013). Epibiotic macrofauna on common minke whales, Balaenoptera acutorostrata Lacépède, 1804, in Icelandic waters. Parasites \& Vectors 6:105. https://doi.org/10.1186/1756-3305-6-105

O'Reilly, M. (1998). Whale-lice (Amphipoda: Cyamidae) and sea lice (Copepoda: Caligidae) from stranded whales in the Firth of Forth. The Glasgow Naturalist 23(3), 24-26.

Rathore, K. (2018). Encounter with a large basking shark.

https://www.youtube.com/watch?v=Bf3zUicz6FY Accessed 15th January 2020.

Scott, A. (1963). Copepods parasitic on the Basking Shark, Cetorhinus maximus. The Irish Naturalists' Journal 14, 177-178. 
Scott, T. \& Scott, A. (1913). British Parasitic Copepoda. Ray Society, London. https://doi.org/10.5962/bhl.title.58672

SMASS (2016). Scottish Marine Animal Stranding Scheme. Annual Report 2016. 1st January to 31st December 2016 for Marine Scotland, Scottish Government.

https://strandings.org/smass/publications/reports/S MASS_Annual_Report_2016.pdf 